\title{
Information Systems Outsourcing: a literature analysis ${ }^{1}$
}

Original Paper sent: September 9, 2005

Request for change: November 30, 2005

Response: January 25, 2006

Second request for change: April 12, 2006

Accepted: July 26, 2006

Section: Research.

Reyes Gonzalez ${ }^{2}$ (mr.gonzalez@ua.es) is a Senior Lecturer in Business Management and Information Systems at the University of Alicante (Spain). Her current research interests are Information Systems Management, E-Business and Outsourcing Processes. She has published articles in several journals, e.g. Information \& Management, Information Technology and People, Logistics Information Management, Total Quality Management, The International Journal of Educational Management, International Journal of Information Management, Information Management \& Computer Security and Industrial Management \& Data Systems.

Jose Gasco (jl.gasco@ua.es) is a Senior Lecturer in Business Management and Human Resources at the University of Alicante (Spain). His current research interests include Human Resources and Information Systems Outsourcing. He has published articles in several journals, namely, Revue Internationale P.M.E., Direction et Gestion des Entreprises, Corporate Communications: An International Journal, The International Journal of Public Sector Management, Business Process Management Journal, Total Quality Management, Information Technology and People, Logistics Information Management, International Journal of Information Management, Information Management \& Computer Security and Industrial Management \& Data Systems.

Juan Llopis (juan.llopis@ua.es) is a Professor of Business Organisation at the University of Alicante (Spain). His current research lines include Organisational Culture, Human Resources, Quality Management, and Information Systems Management. He has published articles in journals such as Information and Management, Total Quality Management, Journal of High Technology Management Research, Corporate Communications: An International Journal, Information Technology and People, Logistics Information Management Journal, International Journal of Value-Based Management, International Journal of Information Management, Information Management \& Computer Security and Industrial Management \& Data Systems.

\section{Abstract:}

Outsourcing has become one of the strategies adopted by businesses to manage their IS. During the last few years, the use of outsourcing has resulted in an increase in the volume of literature devoted to it. We decided therefore to analyse the literature with the aim of identifying the main topics, the methodologies most often applied and the authors and countries that have contributed most to the area of IS Outsourcing. We also intended to offer suggestions on improving research in this field. The paper thus provides a review of articles about IS Outsourcing published in the most prestigious journals of the IS area and journals of Management or Business.

\section{Keywords:}

${ }^{1}$ The authors would like to thank the editor and the three anonymous reviewers for all their suggestions.

${ }^{2}$ Corresponding author: Reyes Gonzalez. Department of Business Organisation. University of Alicante. Zip Code: 03080. San Vicente del Raspeig. Alicante. SPAIN. Phone \& Fax No.: +34965903606. E-mail address: mr.gonzalez@ua.es. 
Information Systems, Outsourcing, Literature Review. 


\section{Introduction}

Outsourcing has become a basic strategy of the IS field [3] and has experienced a considerable growth in recent years. According to some analysts, this growth will continue in the near future. Forrester, for example, forecasted that European enterprises will spend over 128 billion $€$ on computer outsourcing in 2008 [56] and the Gartner group has estimated that the worldwide IT outsourcing market will grow from the $\$ 180.5$ billion revenues in 2003 to $\$ 253.1$ billion in 2008 at a compound annual growth rate of $7.2 \%$. Some of the largest IS outsourcing providers are IBM, EDS, CSC, Hewlett Packard, Oracle, General Electric, HSBC [61]. These traditional enterprises have been competing in recent years with new providers, including Tata Consulting, Infosys, Wipro, Satyam, HCL-Perot and Patni Computers [145] located in newly emerging countries and regions, such as India and South-East Asia.

The number of publications dedicated to outsourcing has increased in recent years and this was our reason to investigate and reflect on what is known about IS outsourcing. Studies have pursued a wide range of objectives. Many analysed the IS area as a whole [4, 40,177], or specific areas such as DSS [5, 53], or Expert Systems [188]; to focus on statistical or methodological problems related to this area $[21,71]$; they also attempted to analyse the most influential journals in the study of IS [37, 82]; and many other topics, some as new as Electronic Commerce [174]. However, with the exception of the work of Dibbern, Goles, Hirschheim and Jayatilaka [46], no literature review on IS outsourcing has been performed.

IS outsourcing first appeared as a distinct area of IS Management Issues in the literature scheme designed by Barki, Rivart and Talbot [20]. The topic appeared again in the General IS Management area of the study by Claver, Gonzalez and Llopis [35]. Our aim was to analyse the IS outsourcing literature to answer questions such as: "What research methods are most commonly used?", "What topics and areas are treated the most often in the IS outsourcing field?", "What is the scope of these studies?" and "Which authors or 
countries stand out in the research about this phenomenon?" Questions similar to these have already been raised with the objective: "To improve our knowledge of this booming field."

\section{Data Collection}

We decided to focus our study on articles published in journals that enjoy hogh prestige in the IS area, not therefore including sources such as books or papers presented at conferences. This was based on the belief that practitioners and academics prefer using journals to acquire and disseminate new knowledge [49, 142]. Other means, such as books, are normally confined to the dissemination of previously established knowledge [74]. We would, however, like to note that certain books [80, 156] and conferences (e.g. ICIS, HICSS and ECIS) are of importance in this field. We did not consider work in the trade or popular press. We selected journals from lists of various authors $[26,101,123,146,164]$.

The resulting list of journals can be found in Table 1. They are included in the ABI-Inform database, widely recognised in the Economics and Business Administration area, and used in other studies whit similar objectives [85, 126]. Furthermore, all the journals were included in the Social Sciences Citation Index or the Science Citation Index in 2004. The journals belong both to the IS area and others related to Management or Business issues in which articles on IS are periodically published. We left out some relevant journals because they had published no articles on IS outsourcing. The Sloan Management Review changed its name to MIT Sloan Management Review in 2000; we carried out our study of articles published under both names.

TABLE 1 near here please

We searched the ABI database for articles with the terms outsourcing and IT or Information Technology or IS or Information System or ICT or Systems Management, without limiting the search date in their abstracts or keywords or full text. We realised that 
many journals were not included on the database for all the years in which articles could be published and therefore decided to complete the search manually, focusing mainly on selected articles as well as reference works and looking at the manual indexes of the journals.

We obtained a total initial sample of 142 articles, four of which were removed from the study because they merely expressed an opinion of the editor or some expert in the topic and could not be regarded as scientific papers with an established methodology. We equally removed another article, a case study, because it was a classroom teaching text, not a research work. Another six articles had to be removed because they discussed other topics [32, 36]. A total of 131 articles therefore were retined in the final sample; these were read carefully and are among the References.

\section{Results.}

\subsection{Period Covered and Journals Analysed}

Based on our work, articles on IS outsourcing have been published for 18 years, the earliest dating back to 1988 and the most modern ones being published in 2005. No articles on IS outsourcing were published between 1988, when one article was released, and 1992. However, since then, the number of publications has soared as a result of the Kodak effect ${ }^{3}$ [121], after the Eastman Kodak Company outsourced its DP function to four vendors led by IBM and including DEC, Businessland and Anderson Consulting too. This deal signalled the start of IS outsourcing megadeals and also legitimised outsourcing. Prior to this, outsourcing had apparently raised little interest $[77,89]$. It is interesting to note that the article published in 1988 [143] did not use the term outsourcing anywhere in the text but used Facilities Management instead. The term outsourcing can be traced back to the 1990s [170] and in 2005 the largest number of articles (19) was published.

\footnotetext{
${ }^{3}$ In 1989.
} 
In order to better analyse the growth, we divided the period under study into three blocks, each of which covered five years ${ }^{4}$ as can be seen in Figure 1, where the number above each column is the number of articles published within each period. The growth in the number of articles shows that interest in the topic is increasing.

FIGURE 1 near here please

TABLE 2 near here please

It can be observed in Table 2 that JIT is the journal which has published the highest number of IS outsourcing articles (21), followed at some distance by I\&M with 16 . It can be seen that the journals that have published most articles are classified as IS journals. However SMR/MITSMR stands out both by the number of articles it has published, representing the $6.9 \%$ of all those analysed, and by their impact (important, oft-cited articles in this field [104, 107, 133] appeared in it).

${ }_{4}$ This is so because, although the first block theoretically corresponds to the period comprised between 1988 and 1995, articles were only published in 5 of those 8 years, namely in 1988 and between 1992 and 1995. 


\subsection{Research Methodologies}

Our analysis of the method used drew on the study by Claver, Gonzalez and Llopis, which was based on the work of Alavi and Carlson for the classification of theoretical studies and Van Horn [175] for classification of empirical studies.

Theoretical studies can be divided into conceptual, illustrative and applied-concept ones. They are mainly based on ideas, structures and speculations rather than on the systematic and direct observation of reality. Although this articles can contain some empirical data, they play a secondary support role; the emphasis is on ideas rather than on data.

- Conceptual studies describe structures, models or theories and provide explanations or reasons.

- Illustrative studies basically try to guide the practice, offer recommendations for action and explain stages to be fulfilled. They focus on the 'what' and the 'how' rather than on the 'why'.

- Applied-concept studies are a mixture of the two; they have both conceptual and explanatory elements.

Empirical studies have been divided into case studies, field studies, field experiments and laboratory experiments, but we found no examples of the last two in the articles analysed. Thus we decided to classify the articles into: case studies; field studies; case and field studies; and others.

- Case studies are becoming more and more widespread in the IS area. They analyse a phenomenon in its natural environment, obtaining data about it through direct observation; interviews; document analysis; etc. The problem with this basically qualitative data collection method is that, because it tends to focus on the analysis of one or a few cases, generalising the results is difficult $[51,190]$. Case studies have been criticised for their lack of scientific rigour. However, this is because it has often been applied to works that only provide a mere set of anecdotes [110]. 
- A field study normally analyses several organisations using an experimental design but little experimental control; researchers collect information about uncontrolled situations. This characteristic is shared with the case study. However, a field study uses quantitative methods in analysing the information, which usually is obtained by interviewing personel. This has the drawback that the information loses depth and richness.

- A good way to overcome the inconveniences and boost the advantages of field and case studies is to use them jointly. A large amount of data is required to isolate the effects of the many variables selected by the researcher [75].

TABLE 3 near here please

Table 3 shows that the majority of the articles in our review were empirical (63.4\%). However, although the number of theoretical and empirical articles was nearly the same (17 versus 18 ) during the first five-year period, from then on, the percentage of empirical articles increased while the number of theoretical articles decreased. This might have been the result of the attempts to validate existing theories or construct new ones based on empirical data.

Among the theoretical methods, applied-concept studies were the most common, followed by illustrative ones and the conceptual ones. The field study stands out as the most often used among the empirical methods, followed by the case studies. These results are in keeping with the conclusions of previous works [e.g., 17], which showed the importance of qualitative methods in the IS area. We found 6 articles classified as empirical that used other methods: there was an article in which a review of the literature on ASP (Application Service Providers) was made; four more articles were devoted to the study of press advertisements or news items; and another analysed finantial information about the enterprises.

FIGURE 2 near here please

Figure 2 shows the most commonly used methods; from this it can be inferred that the field study is most frequently used in the study of 
outsourcing. We noted that IS journals show a much larger proportion of empirical articles (65.4\%), whereas in generalist publications, with more empirical articles also, the difference in percentage with merely theoretical ones is smaller.

\subsection{Topics and Scope}

An analysis of the most frequent outsourcing topics is presented in Table 4. Our main problem in making this analysis was that we had only a previous study by Dibbern, Goles, Hirschheim and Jayatilaka on IS outsourcing for guidance ${ }^{5}$, with two other articles which involved reviews of literature on ASP [161] and Global Outsourcing [162]. The topic classification we used was therefore based on our reading of the articles and previous knowledge of the topic. Also analysis of previous reviews of IS research gave us some insight. More precisely, we decided to use the keywords of the specific article being analysed as the basis for identification of the topic/s under which it should be classified. The resulting categories were neither mutually exclusive nor collectively exhaustive; so an article could be classified into one or more categories and more topics were found as the number of articles increased. Previous studies have used comparable approaches to classification, the similarities being based on:

- Not limiting or forcing categories or topics based on preconceptions;

- Allowing the emergence of more topics as more sources were found and analysed.

- Finishing when "saturation" occured - when no more topics arose.

Table 4 shows the number of articles dealing with each topic and the percentage of the total that they represented. In our case the total

\footnotetext{
${ }^{5}$ Most of the works analised by Dibbern, Goles, Hirschheim and Jayatilaka have been analysed in our paper, but the first study is limited to the works published till 2000, and our paper analyses works till 2005. For this reason the study of Dibbern, Goles, Hirschheim and Jayatilaka analyses 84 works and our paper analyses 131. Whereas their work studies the objectives of the research in IS outsourcing field based on a predetermined model, we pretend to arrive to a model along the analysis of the topics on IS outsourcing literature. Finally, in the paper of Dibbern, Goles, Hirschheim and Jayatilaka there is not a study of the IS outsourcing literature along the time, and we pretend to study this evolution.
} 
was 205, not 131, since articles were sometimes dealt with more that one topic.

TABLE 4 near here please

We next classified the topics into five broad areas:

1. Outsourcing from the Perspective of the Client;

2. Outsourcing from the Perspective of the Provider;

3. Outsourcing from the Perspective of the Relationship;

4. Outsourcing from the Perspective of Economic Theories;

5. Others.

1. Outsourcing from the Perspective of the Client; this included general views of computer outsourcing, explaining how it arose, how it evolved, and how much it had grown [27]. It also included discussion of the decision-making process prior to the decision to outsource and afterwards [38] and the main determining factors behind the decision [68]. At the other end of the spectrum, the discussion of possible risks of outsourcing were explained too, along with the cost and inconvenience that outsourcing could generate. Finally, it dealt with articles discussing the factors required for the outsourcing relationship to be successful [114].

Broadly speaking, this area covers topics that give advice to potential IS outsourcing clients.

2. Outsourcing from the Perspective of the Provider: this area focuses on the supply side of outsourcing; i.e., on provider firms and the services they deliver. Three specific topics can be found in this area: computer outsourcing services in general (evolution and transformation from focusing on consultancy, through hardware and software provision, to offering outsourcing services through megadeals). This was possible because of fusions and acquisitions and by specialisation in specific industries, such as the chemical, healthcare or financial industries [43]. Similarly, due to the obligation of public administration to put contracts out to public tender, many computer service providers have had to 'reinvent' themselves as specialists in strategic outsourcing services [150]. 
Another topic is that of ASP, the application providers that supply these services through telecommunications. The literature of this issue, though abundant, is also very recent.

Global or Offshore Outsourcing are recent operations led by computer service providers that operate on an international scale, e.g., in India or China, hiring a workforce in countries with low incomes but enough computer knowledge [25]. Data entry was one of the first activities to be contracted in this way, because it required a low level of knowledge and very limited relationship between provider and client [165].

In short, this area does not give advice to customers but seeks to supply information about providers.

3. Outsourcing from the Perspective of the Relationship. We grouped together the papers that analysed outsourcing on the basis of the links that exist between client and provider. One of the major links is the outsourcing contract; the providers often call themselves 'strategic partners' with the customer, but the success of the relationship depends on a well-structured contract. A good relationshp needs a detailed material developed by legal advisors [48].

Closely related to this is the method of assessing the quality of the outsourcing service, i.e. measurement of the value of the IS outsourcing versus its cost (assessing the fair price). This has not proved easy [79], since conventional methods for evaluating asset profitability cannot be applied [185].

The final topic focuses on the way that client-provider relationships must be established [90, 91].

\section{Outsourcing from the Perspective of Economic Theories.}

Among the many articles dealing with the economics of outsourcing, they involve agency theory [18], transaction cost theory [10] and others such as the game theory [52], resource-based theory, and resource-dependence theory [31]. They are all topics repeatedly 
found in most articles but in some it forms an essential part: these are the articles that we classified here.

5. Others. We included topics here dealing with such issues as nationality, when an attempt was made either to define national differences [12] or to analyse outsourcing for developing countries, such as Nigeria [1]. We also included here the topic which deals with the industrial problems involved in IS outsourcing, e.g. in the healthcare or financial industries, at universities, or in relation to the differences between the public and private sector [6, 122]. A final topic referred to computer staff, since outsourcing poses a potential threat to their jobs [9, 81, 129].

FIGURE 3 near here please

Figure 3 shows the topics that have been most frequently discussed in IS outsourcing: reasons for it clearly are important. It also shows the evolution of these topics over time. The reasons and the general view of the phenomenon are now less important. Much more attention has been paid, though, to the relationships between clients and providers and the use of the transaction cost theory. Also the number of articles devoted to the study of ASP has recently dominated the scene.

It is also worth mentioning the increase in the number of articles focusing on Offshore or Global Outsourcing. The use of cheaper communications technology, the Internet, economic globalisation, and easy access to IT professionals with lower salaries are some of the reasons for this [95].

FIGURE 4 near here please

A joint analysis of the general areas helps to explain this evolution (see Figure 4). The area most frequently found was the study of outsourcing from the perspective of the client, though this topic was less discussed in recent years.

It can be seen that, although the study of outsourcing from the perspective of the provider was less studied at first, it increased in interest, particularly after 2001 . 
The use of economic theories as an explanation of outsourcing strategy, has also started raising more interest: This may be a symptom of maturity in the area, introducing more rigour through the use of theories.

Finally, articles on both of the influence exerted by outsourcing on computer staff and of the national and/or industrial problems associated with outsourcing have increased.

Table 5 shows the scope of the IS activities outsourced: i.e. is it the entire IS function or only part of it?

TABLE 5 near here please

Most of the articles dealt with IS outsourcing in general (77.1\%). In most cases, the papers provide no details about the type of activities that are or could be the object of outsourcing. Only some, mostly the empirical ones, specify these activities. Thus, Adeleye, Annansingh and Nunes dealt with: Training and education; software development; software maintenance; data communication networks; support operations; disaster recovery; telephone client support; development of a fully integrated system; data centre operation; etc. Instead, Jurison mentioned the following activities in his primarily theoretical work: data processing operation; telecommunications; applications development; and hardware maintenance.

$13.7 \%$ of the articles focused on Software Development. Also, many of the articles dealt with the topic of Global Outsourcing [44], as software development is the task in which provider firms from emergent countries have specialised. A small number of articles (8.4\%) were devoted to Applications rental services, mostly through ASP [58, 172]. Finally, only one article dealt with E-Commerce outsourcing [97].

\subsection{Authors and Countries}

Other studies identified the authors who publish the most as well as their nationalities [e.g. 167]. Based on them, we present Table 6 .

TABLE 6 
The nationality corresponded to that of the university or other organisation for which the author was working when he/she published the article. A count was performed of the number of times each author made a contribution without making any distinctions in value (whether the researcher appeared as author or co-author of the article $)^{6}$.

Although the most prolific author in this field was from United Kingdom, most came from the United States of America, with several other countries appearing also. A more in-depth analysis of the nationality of the authors can be found in Table 7, which shows countries that have contributed most.

TABLE 7 near here please

Value $\mathrm{N}$ stands for the number of times a researcher from a country has published an article. $\mathrm{N}$ consequently reveals how prolific a country is, either in articles or in researchers, or in both. A clear prevalence of the United States $(\mathrm{N}=154)$ over the rest of countries can be easily observed, the United Kingdom $(\mathrm{N}=54)$ ranking second. Although the number of articles published from other countries is smaller, we highlight the significance of Asian countries, especially South-East Asia, in which Global Outsourcing had a very strong presence.

When we analysed the number of articles published by one author or collectively by several authors, the overall result was largely in keeping with that obtained in other studies [140], only $24 \%$ of the articles analysed had one author, with 39\% having two.

Although no statistic correlation exists between the number of authors and the time-period, the number of articles published by one author seems to have remained stable throughout the period covered, whereas the number of articles published by two or more has increased. This tendency toward co-authorship could suggest a degree of maturity in the creation and consolidation of research

\footnotetext{
${ }^{6}$ For example, if the $\mathrm{N}$ that accompanies an author is 2 , he/she may have published those two papers alone or with someone else.
} 
teams. As Nath and Jackson point out, co-authorship is a step from'little science' to 'big science'.

\section{Conclusions}

Our analysis has shown that the study of outsourcing has progressively increased ever since its start in the 1960's. The articles were mainly empirical, a field study being the method preferred by researchers when they try to explain outsourcing. New topics have appeared in the last few years, among them its influence on computer staff and its threat to the jobs of Western computer specialists.

\section{References}

[1]B.C. Adeleye., F. Annansingh and M.B. Nunes. "Risk management practices in IS outsourcing: an investigation into commercial banks in Nigeria". International Journal of Information Management. 24 (2), 2004, pp. 167-180.

[2]M. Agrawal, G. Hariharan, R. Kishore and H.R. Rao. "Matching Intermediaries for Information Goods in the Presence of Direct Search: an Examination of Switching Costs and Obsolescence of Information". Decision Support Systems. 41(1), 2005, pp. 20-36.

[3]O.J. Akomode, B. Lees, and C. Irgens. "Constructing customised models and providing information to support IT outsourcing decisions". Logistics Information Management. 11 (2), 1998, pp. $114-127$.

[4]M. Alavi and P. Carlson. "A Review of MIS Research and Disciplinary Development". Journal of Management Information Systems. 8 (4), 1992, pp. 4562.

[5]M. Alavi and E.A. Joachimsthaler. "Revisiting DSS Implementation Research: A Meta-Analysis of the Literature and suggestions for Researchers". MIS Quarterly, 16 (1), 1992, pp. 95-116.

[6]D. Allen, T. Kern and D. Mattison. "Culture, power and politics in ICT outsourcing in higher education institutions". European Journal of Information Systems. 11 (2), 2002, pp. 159-173.

[7]K. Altinkemer, A. Chaturvedi and R. Gulati. "Information systems outsourcing: Issues and evidence". International Journal of Information Management. 14 (4), 1994, pp. 252-268.

[8]S. Ang and L.L. Cummings. "Strategic response to institutional influences on Information Systems outsourcing". Organization Science. 8 (3), 1997, pp. 235256.

[9] S. Ang and S.A. Slaughter. "Work outcomes and job design for contract versus permanent information systems professionals on software development teams". MIS Quarterly. 25 (3), 2001, pp. 321-350.

[10]S. Ang, S. and D.W. Straub. "Production and transaction economies and IS outsourcing: A study of the U.S. banking industry". MIS Quarterly. 22 (4), 1998, pp. 535-552.

[11]U.M. Apte and R.O. Mason "Global disaggregation of information-intensive services". Management Science. 41 (7), 1995, pp. 1250-1262.

[12]U.M. Apte, M.G. Sobol, S. Hanaoka, T. Shimada, T. Saarinen, T. Salmela and A.P.J. Vepsalainen. "IS outsourcing practices in the USA, Japan and Finland: a comparative study". Journal of Information Technology. 12 (4), 1997, pp. 289304. 
[13]K.P. Arnett and M.C Jones. "Firms that choose outsourcing: A profile". Information \& Management. 26 (4), 1994, pp. 179-188.

[14]B.A. Aubert, S. Rivard and M. Patry. "A transaction cost approach to outsourcing behavior: Some empirical evidence". Information \& Management. 30 (2), 1996a, pp. 51-64.

[15]B.A. Aubert, S. Rivard, and M. Patry. "Development of measures to assess dimensions of IS operation transactions". OMEGA. 24 (6), 1996b, pp. 661-680.

[16]B.A. Aubert, S. Rivard and M. Patry. "A transaction cost model of IT outsourcing". Information \& Management. 41 (7), 2004, pp. 921-932.

[17]Ch. Avgerou. "Information Systems: What sort of science is it? OMEGA. 28, 2000, pp. 567-579.

[18]B. Bahli, B. and S. Rivard. "The information technology outsourcing risk: a transaction cost and agency theory-based perspective" Journal of Information Technology. 18 (3), 2003, pp. 211-221.

[19]L.P. Baldwin, Z. Irani and P.E.D. Love. "Outsourcing information systems: drawing lessons from a banking case study". European Journal of Information Systems. 10 (1), 2001 pp. 15-24.

[20]H. Barki, S. Rivard and J. Talbot. "A Keyword Classification Scheme for IS Research Literature: an Update". MIS Quarterly. 17 (2), 1993, pp. 209-226.

[21]J.J. Baroudi and W.J. Orlikowski. "The problem of Statistical Power in MIS research". MIS Quarterly. 13 (1), 1989, pp. 87-106.

[22]J. Barthélemy. "The Hidden Cost of IT Outsourcing". MIT Sloan Management Review. 42 (3), 2001, pp. 60-69.

[23]J. Barthélemy and D. Geyer. "An Empirical Investigation of IT Outsourcing versus Quasi-outsourcing in France and Germany". Information \& Management. 42(4), 2005, pp. 533-542.

[24]H.K. Bhargava and S. Sundaresan . "Computing as Utility: Managing Availability, Commitment, and Pricing Through Contingent Bid Auctions". Journal of Management Information Systems. 21 (2), 2004, pp. 201-227.

[25]S.C. Bhatnagar and S. Madon. "The Indian software industry: moving towards maturity". Journal of Information Technology. 12 (4), 1997, pp. 277-288.

[26]S. Bhattacharjee, Y.A. Tung and B. Pathak. "Author experiences with the IS Journal Review Process". Communications of the Association for Information Systems. 13, 2004, pp. 629-653.

[27]M. Buck-Lew. "To outsource or not?" International Journal of Information Management. 12 (1), 1992, pp. 3-20.

[28]N.G. Carr. "The End of Corporate Computing". MIT Sloan Management Review. 46(3), 2005, pp. 67-73.

[29]A. Chaudhury, K. Nam and H.R. Rao. "Management of information systems outsourcing: A bidding perspective". Journal of Management Information Systems. 12 (2), 1995, pp. 131-159.

[30]M.J. Cheon, V. Grover and R. Sabherwal. "The Evolution of Empirical Research in IS. A Study in IS Maturity". Information \& Management. 24 (3), 1993, pp. 107-119.

[31]M. Cheon, V. Grover and J. Teng. "Theoretical Perspectives on the Outsourcing of Information Systems". Journal of Information Technology. 10, 1995, pp. 209219.

[32]C. Ching, C.W. Holsapple and A.B. Whinston. "Toward IT support for coordination in network organizations". Information \& Management. 30 (4), 1996, pp. 179-200.

[33]V. Choudhury and S. Sabherwal. "Portfolios of control in outsourced software development projects". Information Systems Research. 14 (3), 2003, pp. 291314. 
[34]T.D. Clark, R.W. Zmud and G.E. McCray. "The Outsourcing of Information Services: Transforming the Nature of Business in the Information Industry". Journal of Information Technology. 10, 1995, pp. 221-237.

[35]E. Claver, R. Gonzalez and J. Llopis. "An analysis of research in information systems (1981-1997)". Information \& Management. 37 (4), 2000, pp. 181-195.

[36]E.K. Clemons, S.P. Reddi and M.C. Row. "The impact of information technology on the organization of economic activity: The "move to the middle" hypothesis". Journal of Management Information Systems. 10(2), 1993, pp. 9-36.

[37]R.B. Cooper, D. Blair and M. Pao. "Communicating MIS research: a citation Study of journal influence". Information Processing \& Management. 29(1), 1993, pp. 113-127.

[38]J. Cronk and J. Sharp. "A Framework for Deciding what to Outsource in Information Technology". Journal of Information Technology. 10, 1995, pp. 259267.

[39]J. Cross. "IT outsourcing: British Petroleum's competitive approach". Harvard Business Review. 73(3), 1995, pp. 94-102.

[40]M.J. Culnan and E.B. Swanson. "Research in Management Information Systems, 1980-84: Points of work and reference". MIS Quarterly. 10(3), 1986, pp. 289302.

[41]W.L. Currie. "Outsourcing in the private and public sectors: An unpredictable IT strategy". European Journal of Information Systems. 4(4), 1996, pp. 226236.

[42]W.L. Currie. "Using multiple suppliers to mitigate the risk of IT outsourcing at ICI and Wessex Water". Journal of Information Technology. 13(3), 1998, pp. 169-180.

[43]W.L. Currie and P. Seltsikas. "Exploring the supply-side of IT outsourcing: Evaluating the emerging role of application service providers". European Journal of Information Systems. 10(3), 2001, pp. 123-134.

[44]M.A. Cusumano. "Software in Ireland; a Balance of Entrepreneurship and Lifestyle Management?". Communications of the ACM. 48(10), 2005, pp. 25-27.

[45]L. De Looff. "Information Systems Outsourcing Decision Making: A framework, organisational theories and case studies". Journal of Information Technology. 10, 1995, pp. 281-297.

[46]J. Dibbern, T. Goles, R. Hirschheim and B. Jayatilaka. "Information Systems Outsourcing: A survey and Analysis of the Leterature". Database for Advances in Information Systems. 35(4), 2004, pp. 6-1026.

[47]A. Diromualdo and V. Gurbaxani. "Strategic Intent for IT Outsourcing". Sloan Management Review. 39(4), 1998, pp. 67-80.

[48]S. Domberger, P. Fernandez and D.G. Fiebig. "Modelling the price, performance and contract characteristics of IT outsourcing". Journal of Information Technology. 15(2), 2000, pp. 107-118.

[49]J.M. Donohue and J.B. Fox. "A multi-method evaluation of journals in the decision and management sciences by US academics". OMEGA. 28(1), 2000, pp. 17-36.

[50]M.J. Earl. "The risk of outsourcing IT". Sloan Management Review. 37(3), 1996, pp. 26-32.

[51]K.M. Eisenhardt. "Building Theories from Case Study Research". Academy of Management Review. 14(4), 1989, pp. 532-550.

[52]R. Elitzur and A. Wensley. "Game theory as a tool for understanding information services outsourcing". Journal of Information Technology. 12(1), 1997, pp. 45-60.

[53]H.B. Eom and S.M. Lee. "A Survey of Decision Support Systems Applications". Interfaces. 20(3), 1990, pp. 65-79.

[54]D. Feeny, M. Lacity and L.P. Willcocks. "Taking the Measure of Outsourcing Providers". MIT Sloan Management Review. 46(3), 2005, pp. 41-48. 
[55]D.F. Feeny and L.P. Willcocks. "Re-designing the IS function around core capabilities". Long Range Planning. 31(3), 1998, pp. 354.-367.

[56]Forrester. "Europe's IT services spending will grow by 57 percent from 2003 to 2008". 2004.2 http://www.tsystems.com/ipl2/statistics/923/downloads/press_kits/

[57]A. Fowler and B. Jeffs. "Examining information systems outsourcing: a case study from the United Kingdom". Journal of Information Technology. 13(2), 1998. pp. 111-126.

[58]R. Fulford and P.E.D. Love. "Propagation of an alternative enterprise service application adoption model". Industrial Management \& Data Systems. 104(5/6), 2004, pp. 450-456.

[59]G.G. Gable. "A multidimensional model of client success when engaging external consultants". Management Science. 42(8), 1996, pp. 1175-1198.

[60]R.D. Galliers and M. Meadows. "A Discipline Divide: Globalization and Parochialism in Information Systems Research". Communications of the Association for Information Systems. 11, 2003, pp. 108-117.

[61] Gartner. "Continued Growth Forecast for IT Outsourcing Segments". Internet $\begin{array}{llll}\text { document, } & \text { get } & 7 & \text { Dec. }\end{array}$ http://www.gartner.com/2_events/conferences/std8.jsp

[62]R. Gonzalez, J. Gasco and J. Llopis. "Information Systems Outsourcing Risks: A Study of Large Firms". Industrial Management \& Data Systems. 105(1), 2005a, pp. 45-62.

[63]R. Gonzalez, J. Gasco and J. Llopis. "Information Systems Outsourcing Reasons in the Largest Spanish Firms". International Journal of Information Management. 25(2), 2005b, pp. 117-136.

[64]P. Gottschalk and H. Solli-Saether. "Critical Success Factors from IT Outsourcing Theories: an Empirical Study". Industrial Management \& Data Systems. 105(6), 2005, pp. 685-702.

[65]P. Gottschalk and J.T. Karlsen. "A Comparison of leadership Roles in Internal IT Projects versus Outsourcing Projects". Industrial Management \& Data Systems. 105(9), 2005, pp. 1137-1149.

[66]A. Gopal, K. Sivaramakrishnan, M.S. Krishnan and T. Mukhopadhyay. "Contracts in Offshore Software Development: An Empirical Analysis". Management Science. 49(12), 2003, pp. 1671-1683.

[67]V. Grover, M.J. Cheon and J.T.C. Teng. "An evaluation of the impact of corporate strategy and the role of information technology on IS functional outsourcing". European Journal of Information Systems. 3(3), 1994a, pp. 179 190.

[68]V. Grover, M.J. Cheon and J.T.C. Teng. "A descriptive study on the outsourcing of information systems functions". Information \& Management. 27(1), 1994b, pp. 33-44.

[69]V. Grover, M.J. Cheon and J.T.C. Teng. "The effect of service quality and partnership on the outsourcing of information systems functions". Journal of Management Information Systems. 12(4), 1996, pp. 89-116.

[70]V. Grover, S.R. Jeong and A.H. Segars. "Information Systems Effectiveness: The Construct Space and Patterns of Applications". Information \& Management. 31(4), 1996, pp. 177-191.

[71]V. Grover, C.C. Lee, and D. Durand. "Analyzing Methodological Rigor of MIS Survey Research from 1980-1989". Information \& Management. 24(6), 1993, pp. 305-317.

[72]V. Grover and R. Sabherwal. "An Analysis of Research in Information Systems from the IS Executive's Perspective". Information \& Management. 16(5), 1989, pp. 233-246.

[73]A. Gupta and S.K. Herath. "Latest Trends and Issues in the ASP Service Market". Industrial Management \& Data Systems. 105(1), 2005, pp. 19-25. 
[74]S. Hamilton and B. Ives. "Knowledge Utilization among MIS Researchers". MIS Quarterly. 20(3), 1982a, pp. 61-77.

[75]S. Hamilton and B. Ives. "MIS Research Strategies". Information \& Management. 5(6), 1982b, pp. 339-347.

[76]R. Heckman. "Organizing and managing supplier relationships in information technology procurement". International Journal of Information Management. 19(2), 1999, pp. 141-155.

[77]R. Hirschheim and J. Dibbern, "Information Systems Outsourcing in the New Economy - An Introduction", in: R. Hirschheim, A. Heinzl and J. Dibbern (Eds.) Information Systems Outsourcing. Enduring Themes, Emergent Patterns and Future Directions (Springer, Berlin, 2002) pp. 3-23.

[78]R. Hirschheim and M. Lacity. "The myths and realities of information technology insourcing". Communications of the ACM. 43(2), 2000, pp. 99-107.

[79]R. Hirschheim and S. Smithson. "A critical analysis of information systems evaluation", in Information Systems Assessment: Issues and Challenges. (Eds.) N. Bjorn-Andersen and G.B. Davis. North Holland. Amsterdan, 1988, pp. 17-37.

[80]R. Hirschheim, A. Heinzl and J. Dibbern (Eds.) Information Systems Outsourcing. Enduring Themes, Emergent Patterns and Future Directions. Springer. Berlin, 2002.

[81]V.T. Ho, S. Ang and D. Straub. "When subordinates become IT contractors: Persistent managerial expectations in IT outsourcing". Information Systems Research. 14(1), 2003, pp. 66-86.

[82]C.W. Holsapple, L.E. Johnson, H. Manakyan and J. Tanner. "A Citation Analysis of Business Computing Research Journals". Information \& Management. 25(5), 1993, pp. 231-244.

[83]Q. Hu, C. Saunders, C. and M. Gebelt. "Research report: Diffusion of information systems outsourcing: A reevaluation of influence sources". Information Systems Research. 8(3), 1997, pp. 288-301.

[84]R.L. Huber. "How Continental Bank outsourced its "crown jewels". Harvard Business Review. 71(1), 1993, pp. 121-129.

[85]M.I. Hwang and R.G. Thorn. "The effect of User Engagement on System Success: A meta-analytical Integration of research Findings". Information \& Management. 35(4), 1999, pp. 229-236.

[86]B. Ives, S. Hamilton and G.B. Davis. "A Framework for Research in Computer Based Management Information Systems". Management Science. 26(9), 1980, pp. 910-934.

[87]B. Ives and M. Olson. "User involvement and MIS success: a review of research". Management Science. 30(5), 1984, pp. 586-603.

[88]B. Jayatilaka, A. Schwarz and R. Hirschheim. "Determinants of ASP choice: an integrated perspective". European Journal of Information Systems. 12(3), 2003, pp. 210-224.

[89]J. Jurison. "The Role of Risk and Return in Information Technology Outsourcing Decisions". Journal of Information Technology . 10(4), 1995, pp. 239-247.

[90]T. Kern and K. Blois. "Norm development in Outsourcing Relationships". Journal of Information Technology. 17(1), 2002, pp. 33-42.

[91]T. Kern and L. Willcocks. "Exploring relationships in information technology outsourcing: The interaction approach". European Journal of Information Systems. 11(1), 2002, pp. 3-19.

[92]T. Kern, L.P. Willcocks and E. Van Heck. "The winner's curse in IT outsourcing: Strategies for avoiding relational trauma". California Management Review. 44(2), 2002, pp. 47-69.

[93]K. Ketler and J. Walstrom. "The outsourcing decision". International Journal of Information Management. 13(6), 1993, pp. 449-459. 
[94]A.M. Khalfan. "Information security considerations in IS/IT outsourcing projects: a descriptive case study of two sectors". International Journal of Information Management. 24(1), 2004, pp. 29-42.

[95]N. Khan and G. Fitzgerald. "Dimensions of Offshore Outsourcing Business Models". Journal of Information Technology Cases and Applications. 6(3), 2004, pp. 35-50.

[96]W.R. King and Y. Malhotra. "Developing a framework for analyzing IS sourcing". Information \& Management. 37(6), 2000, pp. 323-334.

[97]R. Kishore, M. Agrawal and H.R. Rao. "Determinants of sourcing during technology growth and maturity: An empirical study of e-Commerce sourcing". Journal of Management Information Systems. 21(3). 2004, pp. 47-82.

[98]R. Kishore, H.R. Rao, K. Nam, S. Rajagopalan and A. Chaudhury. "A Relationship Perspective on IT Outsourcing". Communications of the ACM. 46(12), 2003, pp. 87-92.

[99]R. Klepper. "The management of partnering development in IS outsourcing". Journal of Information Technology. 10, 1995, pp. 249-258.

[100]C. Koh, S. Ang and D.W. Straub. "IT Outsourcing Success: A Psychological Contract Perspective". Information Systems Research. 15(4), 2004, pp. 356373.

[101]Ch. Koh. "IS journal review process: a survey on IS research practices and journal review issues". Information \& Management. 40(8), 2003, pp. 743-756.

[102]R. Kohli and S. Devaraj. "Measuring Information technology Payoff: a metaanalysis of structural variables in firm-level empirical research". Information Systems Research. 12(2). 2003, pp. 127-145.

[103]S. Krishna, S. Sahay, S. and G. Walsham, G. "Managing cross-cultural issues in global software outsourcing". Communications of the ACM. 47(4), 2004, pp. 62-66.

[104]M. Lacity and R. Hirschheim. "The Information Systems outsourcing bandwagon". Sloan Management Review. 35(1), 1993, pp. 73-86.

[105]M.C. Lacity and L.P. Willcocks. "An empirical investigation of information technology sourcing practices: Lessons from experience". MIS Quarterly. 22(3), 1998, pp. 363-408.

[106]M.C. Lacity, L.P. Willcocks and D.F. Feeny. "IT outsourcing: Maximize flexibility and control". Harvard Business Review. 73(3), 1995, pp. 84-93.

[107]M.C. Lacity, L.P. Willcocks and D.F. Feeny. "The value of selective sourcing". Sloan Management Review. 37(3), 1996, pp. 13-25.

[108]V.S. Lai and R.K. Mahapatra. "Exploring the Research in Information Technology Implementation". Information \& Management. 32(4), 1997, pp. 187201.

[109]M.C. Lander, R.L. Purvis, G.E. McCray and W. Leigh. "Trust-building mechanisms utilized in outsourced IS development projects: a case study". Information \& Management. 41(4), 2004, pp. 509-528.

[110]A.S. Lee. "A Scientific Methodology for MIS Case Studies". MIS Quarterly. 13(1), 1989, pp. 33-50.

[111]J-N. Lee. "The impact of knowledge sharing, organizational capability and partnership quality on IS outsourcing success". Information \& Management. 38(5), 2001, pp. 323-335.

[112]J-N. Lee and Y-G. Kim. "Effect of partnership quality on IS outsourcing: Conceptual framework and empirical validation". Journal of Management Information Systems. 15(4), 1999, pp. 29-61.

[113]J-N. Lee, M.Q. Huynh, R. C-W. Kwok and S-M. Pi. "IT outsourcing evolution Past, present, and future". Communications of the ACM. 46(5), 2003, pp. 8489. 
[114]J-N. Lee, S.M. Miranda, S.M. and Y-M. Kim. "IT Outsourcing Strategies: Universalistic, Contingency, and Configurational Explanations of Success". Information Systems Research. 15(2), 2004, pp. 110-131.

[115]M.K.O. Lee. "IT outsourcing contracts: practical issues for management". Industrial Management \& Data Systems. 96(1), 1996, pp. 15-20.

[116]N, Levina and J.W. Ross. "From the vendor's perspective: Exploring the value proposition in information technology outsourcing". MIS Quarterly. 27(3), 2003, pp. 331-364.

[117]E. Lewis. "Using the risk-remedy method to evaluate outsourcing tenders". Journal of Information Technology. 14(2), 1999, pp. 203-211.

[118]Y. Lichtenstein. "Puzzles in Software Development Contracting". Communications of the ACM. 47(2), 2004, pp. 61-65.

[119]J. Lim, V.J. Richardson and T.L. Roberts. "Information technology Investment and Firm Performance: a meta-analysis". Proceedings of the $37^{\text {th }}$ Hawaii International Conference on System Sciences. 2004.

[120]L. Loh and N. Venkatraman. "Determinants of information technology outsourcing: A cross-sectional analysis". Journal of Management Information Systems. 9(1), 1992a, pp. 7-24.

[121]L. Loh and N. Venkatraman. "Difusion of Information Technology Outsourcing: Influence sources and the Kodak Effect". Information Systems Research. 3(4), 1992b, pp. 334-358.

[122]D.P. Lorence and A. Spink. "Healthcare information systems outsourcing". International Journal of Information Management. 24(2), 2004, pp. 131-145.

[123]P.B. Lowry, D. Romans and A. Curtis. "Global Journal Prestige and Supporting Disciplines: A Scientometric study of Information Systems Journals". Journal of the Association for Information Systems. 5(2), 2004, pp. 29-77.

[124]Q. Ma; J.M. Pearson and S. Tadisina. "An Exploratory Study into Factors of Service Quality for Application Service Providers". Information \& Management. 42(4), 2005, 1067-1080.

[125]M.A. Mahmood, J.M. Burn, L.A. Gemoets and C. Jacquez. "Variables affecting information technology end-user satisfaction: a meta-analysis of the empirical literature". International Journal of Human-Computer Studies. 52(4), 2000, pp. 751-771.

[126]M.A. Mahmood, L. Hall and D.L. Swanberg. "Factors affecting information technology usage: a meta-analysis of the empirical literature". Journal of Organizational Computing and Electronic Commerce. 11(2), 2001, pp. 107130.

[127]C.L. Mann. "What Global Sourcing Means for U.S IT Workers and for the U.S. Economy". Communications of the ACM. 47(7), 2004, pp. 33-35.

[128]M.G. Martinsons. "Outsourcing Information Systems: A Strategic Partnership with Risk". Long Range Planning. 26(3), 1993. pp. 18-25.

[129]M.G. Martinsons and C. Cheung. "The impact of emerging practices on IS specialists: perceptions, attitudes and role changes in Hong Kong". Information \& Management. 38(3), 2001, pp. 167-183.

[130]N. Matloff. "Globalization and the American IT Worker". Communications of the ACM. 47(11), 2004, pp. 27-29.

[131]L. McAulay, N. Doherty and N. Keval. (2002). "The stakeholder dimension in information systems evaluation". Journal of Information Technology. 17(4), 2002, pp. 241-255.

[132]G. McBride and R. Rademacher. "A profile of IS research: 1986-1991". Journal of Computer Information Systems. 33(1), 1992, pp. 1-5.

[133]F.W. McFarlan and R.L. Nolan. "How to manage an IT outsourcing alliance". Sloan Management Review. 36(2), 1995, pp. 9-23. 
[134]K. McLellan, B.L. Marcolin and P.W. Beamish. "Financial and Strategic Motivations behind IS Outsourcing". Journal of Information Technology. 10(4), 1995, pp. 299-321.

[135]P.L. McLeod. "An assessment of the experimental literature on electronic support of group work: results of a meta-analysis". Human-Computer Interaction. 7(3), 1992, pp. 257-280.

[136]V. Michell and G. Fitzgerald. "The IT outsourcing market-place: vendors and their selection". Journal of Information Technology. 12(3), 1997, pp. 223-237.

[137]S.M. Miranda and C.B. Kavan. "Moments of Governance in IS Outsourcing : Conceptualizing Effects of Contracts on Value Capture and Creation". Journal of Information Technology. 20(3), 2005, pp. 152-169.

[138]A.R. Montazemi and S. Wang. "The effects of Modes of Information presentation on decision-making: a review and Meta- analysis". Journal of Management Information Systems. 5(3), 1989, pp. 101-127.

[139]K. Nam, S. Rajagopalan, H.R. Rao and A. Chaudhury. "A two-level investigation of information systems outsourcing". Communications of the ACM. 39(7), 1996, pp. 36-44.

[140]R. Nath and W.N. Jackson. "Productivity of Management Information Systems Researchers: Does Lotka's Law Apply?". Information Processing \& Management. 27(2/3), 1991, pp. 203-209.

[141]E.W.T. Ngai and F.K.T. Wat. "A literature review and classification of electronic commerce research". Information \& Management. 39(5), 2002, pp. 415-429.

[142]J.H. Nord and G.D. Nord. "MIS Research: Journal Status assessment and Analysis". Information \& Management. 29(1), 1995, pp. 29-42.

[143]M. Owen and D. Aitchison. "Facilities Management - The Alternative Information Technology Revolution". Industrial Management \& Data Systems. May/Jun. 1988, pp. 15-17.

[144]P.C. Palvia. "A dialectic view of information systems outsourcing: Pros and cons". Information \& Management. 29(5), 1995, pp. 265-275.

[145]S. Palvia. "Global Outsourcing of IT and IT Enabled Services: Impact on US and Global Economy". Journal of Information Technology Cases and Applications. 5(3), 2003, pp. 1-11.

[146]K. Peffers and T. Ya. "Identifying and evaluating the universe of outlets for Information Systems Research: ranking the journals". Journal of Information Technology Theory and Application. 5(1), 2003, pp. 63-84.

[147]A. Pinnington and P. Woolcock. "How far is IS/IT outsourcing enabling new organizational structure and competences?" International Journal of Information Management. 15(5), 1995, pp. 353-365.

[148]A. Pinnington and P. Woolcock. "The role of vendor companies in IS/IT outsourcing". International Journal of Information Management. 17(3), 1997, pp. 199-210.

[149]Z. Qu and M. Brocklehurst. "What will it take for China to become a competitive force in offshore outsourcing? An analysis of the role of transaction costs in supplier selection". Journal of Information Technology. 18(1), 2003, pp. 53-67.

[150]J.B. Quinn and F.G. Hilmer. "Strategic outsourcing". Sloan Management Review. 35(4). 1994, pp. 43-55.

[151]R. Ravichandran and N.U. Ahmed. "Offshore systems development". Information \& Management. 4(1), 1993, pp. 33-40.

[152]W.B. Richmond and A. Seidmann. "Software development outsourcing contract: Structure and business value". Journal of Management Information Systems. 10(1), 1993, pp. 57-72.

[153]W.B. Richmond, A Seidmann and A.B. Whinston. "Incomplete Contracting Issues in Information Systems Development Outsourcing". Decision Support Systems. 8(5), 1992, pp. 459-477. 
[154]T. Saarinen and A.P.J. Vepsalainen. "Procurement strategies for information systems". Journal of Management Information Systems. 11(2), 1994, pp.187208.

[155]R. Sabherwal. "The role of trust in outsourced is development projects". Communications of the ACM. 42(2), 1999, pp. 80-87.

[156]S. Sahay, B. Nicholson and S. Krishna (Eds.). Global IT Outsourcing. Software Development Across Borders. Cambridge University Press. Cambridge. 2003.

[157]S.P. Saraswat and J.T. Gorgone. "Multinational issues in information technology". Information \& Management, 21(2), 1991, pp. 111-121.

[158]C. Saunders, M. Gebelt and Q. Hu. "Achieving success in information systems outsourcing". California Management Review. 39(2), 1997, p. 63-79.

[159]Z. Shi, A.S. Kunnathur and T.S. Ragu-Nathan. "IS Outsourcing Management Competence Dimensions: Instrument Development and Relationship Exploration". Information \& Management. 42(6), 2005, pp. 901-919.

[160]S. Slaughter and S. Ang. "Employment outsourcing in information systems". Communications of the ACM. 39(7), 1996, pp. 47-54.

[161]M.A. Smith and R.L. Kumar. "A theory of application service provider (ASP) use from a client perspective". Information \& Management. 41(8), 2004, pp. 977-1002.

[162]M.A. Smith, S. Mitra and S. Narasimhan. "Offshore outsourcing of software development and maintenance: A framework for issues". Information \& Management. 31(3), 1996, pp. $165-175$.

[163]M.A. Smith, S. Mitra and S. Narasimhan. "Information systems outsourcing: A study of pre-event firm characteristics" Journal of Management Information Systems. 15(2), 1998, pp. 61-93.

[164]S. Smithson and R. Hirschheim. "Analysing information systems evaluation: Another look at an old problem". European Journal of Information Systems. 7(3), 1998, pp. 158-17.

[165]M.G. Sobol and U. Apte. "Domestic and global outsourcing practices of America's most effective IS users". Journal of Information Technology. 10, 1995, pp. 269-280.

[166]R.A. Sommer. "Business process flexibility: A driver for outsourcing". Industrial Management \& Data Systems. 103(3/4), 2003, pp. 177-183.

[167]R. Suomi. "On the Nationality Balance of Authors and References in Selected MIS Journals". Information \& Management. 24(6), 1993, pp. 339-347.

[168]A. Susarla, A. Barua and A.B. Whinston. "Understanding the service component of Application Service Provision: an empirical analysis of satisfaction with ASP services". MIS Quarterly. 27(1), 2003, pp. 91-123.

[169]M.H.A. Tafti. "Risks Factors Associated with Offshore IT Outsourcing". Industrial Management \& Data Systems. 105(5), 2005, pp. 549-560.

[170]Ch.B. Tayntor. "A Practical Guide to Staff Augmentation and Outsourcing". Information Systems Management. 18(1), 2001, pp. 84-91.

[171]J.T.C. Teng, M.J. Cheon and V. Grover. (1995). "Decisions to outsource information systems functions: Testing a Strategy-Theoretic Discrepancy Model". Decision Sciences. 26(1), 1995, pp. 75-103.

[172]S. Trimi, S.M. Lee and D.L. Olson. "Alternative Means to Implement ERP. Internal and ASP". Industrial Management \& Data Systems. 105(2), 2005, pp. 184-192.

[173]G.G. Udo. (2000). “Using analytic hierarchy process to analyze the information technology outsourcing decision". Industrial Management \& Data Systems. 100(9), 2000, pp. 421-429.

[174]A. Urbaczewski, L.M. Jessup and B. Wheeler. "Electronic Commerce Research: a Taxonomy and Synthesis". Journal of Organizational Computing and Electronic Commerce. 12(4), 2002, pp. 263-305. 
[175]R.L. Van Horn. "Empirical Studies of Management Information Systems". Data Base. 5(4-5), 1973, pp. 172-180.

[176]N. Venkatraman, N. "Beyond outsourcing: managing IT resources as a value center". Sloan Management Review. 38(3), 1997, pp. 51-64.

[177]I. Vessey, V. Ramesh and R.L. Glass. "Research in Information Systems: an empirical study of diversity in the discipline and its journals". Journal of Management Information Systems. 19(2), 2002, pp. 129-174.

[178]E.A. Walden. "Intellectual Property Rights and Cannibalization in Information Technology Outsourcing contracts". MIS Quarterly. 29(4), 2005, pp. 699-721.

[179]K.R. Walsh. "Analyzing the application ASP concept: Technologies, economies, and strategies". Communications of the ACM. 46(8), 2003, pp. 103107.

[180]K.A. Walstrom and B.C. Hardgrave. "Forums for information systems scholars: III". Information \& Management. 39(2), 2001, pp. 117-124.

[181]E.T.G. Wang, T. Barron and A. Seidmann. "Contracting structures for custom software development: The impacts of informational rents and uncertainty on internal development and outsourcing". Management Science. 43(12), 1997, pp. 1726-1744.

[182]S. Whang. "Contracting for Software Development". Management Science. 38(3), 1992, pp. 307-324.

[183]M.E. Whitman, A.R. Hendrickson and A.M. Townsend. "Research commentary. Academic regards for teaching, research, and service: data and discourse", Information Systems Research. 10(2), 1999, pp. 99-109.

[184]L. Willcocks, G. Fitzgerald and D. Feeny. "Outsourcing IT: The Strategic Implications". Long Range Planning. 28(5), 1995, pp. 59-70.

[185]L. Willcocks, G. Fitzgerald and M. Lacity. "To outsource IT or not? Recent research on economics and evaluation practice". European Journal of Information Systems. 5(3), 1996, pp. 143-160.

[186]L. Willcocks, M. Lacity and G. Fitzgerald. "Information technology outsourcing in Europe and the USA: Assessment issues". International Journal of Information Management. 15(5), 1995, pp. 333-351.

[187]L. Willcocks and T. Kern. "IT outsourcing as strategic partnering: The case of the UK Inland Revenue". European Journal of Information Systems. 7(1), 1998, pp. 29-45.

[188]B.K. Wong and J.A. Monaco. "Expert System Applications in Business: a Review and Analysis of the Literature (1977-1993)". Information \& Management. 29(3), 1995, pp. 141-152.

[189]C. Yang and J-B. Huang. "A decision model for IS outsourcing". International Journal of Information Management. 20(3), 2000, pp. 225-239.

[190]R.K. Yin. "The case Study Crisis: Some Answers". Administrative Science Quarterly. (26), 1981, pp. 58-65. 
Table 1: Journals analysed

\begin{tabular}{|c|c|c|c|c|c|c|c|c|c|}
\hline & $\begin{array}{c}\text { IS } \\
\text { journal } \\
\text { S }\end{array}$ & $\begin{array}{l}\text { Non- } \\
\text { IS } \\
\text { journ } \\
\text { als }\end{array}$ & $\mathrm{ABI}$ & $\begin{array}{c}\text { SSCI } \\
\text { SCI } \\
2004\end{array}$ & $\begin{array}{c}\text { Koh } \\
{[101]}\end{array}$ & $\begin{array}{c}\text { Lowry, } \\
\text { Romans } \\
\text { and } \\
\text { Curtis } \\
\text { [123] }\end{array}$ & $\begin{array}{c}\text { Peffers } \\
\text { and Ya } \\
{[146]}\end{array}$ & $\begin{array}{c}\text { Walstrom } \\
\text { and } \\
\text { Hardsgra } \\
\text { ve [180] }\end{array}$ & $\begin{array}{c}\text { Whitman, } \\
\text { Hendrickso } \\
n \text { and } \\
\text { Townsend } \\
\text { [183] }\end{array}$ \\
\hline CACM & $*$ & & $*$ & $*$ & $*$ & $*$ & - & * & * \\
\hline DSS & $*$ & & $*$ & $*$ & $*$ & $*$ & $*$ & $*$ & $*$ \\
\hline EJIS & $*$ & & $*$ & * & - & $*$ & $*$ & $*$ & - \\
\hline IM\&DS & $*$ & & $*$ & $*$ & - & - & $*$ & - & - \\
\hline I\&M & $*$ & & $*$ & $*$ & $*$ & $*$ & $*$ & $*$ & $*$ \\
\hline ISR & $*$ & & * & $*$ & $*$ & $*$ & $*$ & $*$ & $*$ \\
\hline IJIM & $*$ & & $*$ & $*$ & - & - & $*$ & - & - \\
\hline JIT & $*$ & & $*$ & $*$ & $*$ & - & $*$ & - & - \\
\hline JMIS & $*$ & & $*$ & $*$ & - & $*$ & - & $*$ & $*$ \\
\hline MISQ & $*$ & & $*$ & $*$ & $*$ & $*$ & $*$ & $*$ & $*$ \\
\hline CMR & & $*$ & $*$ & $*$ & - & - & - & - & - \\
\hline DS & & $*$ & $*$ & $*$ & $*$ & - & $*$ & $*$ & $*$ \\
\hline HBR & & $*$ & $*$ & $*$ & $*$ & $*$ & - & $*$ & * \\
\hline LRP & & $*$ & $*$ & $*$ & - & - & - & - & - \\
\hline MS & & $*$ & $*$ & $*$ & $*$ & $*$ & $*$ & $*$ & $*$ \\
\hline SMR/MITSM & & $*$ & $*$ & $*$ & $*$ & - & - & $*$ & $*$ \\
\hline $\mathrm{R}$ & & $*$ & $*$ & $*$ & $*$ & - & $*$ & $*$ & * \\
\hline $\begin{array}{l}\text { OMEGA } \\
\text { OS }\end{array}$ & & $*$ & $*$ & $*$ & $*$ & $*$ & $*$ & - & - \\
\hline
\end{tabular}

CACM=Communications of the ACM; DSS=Decision Support Systems; EJIS=European Journal of Information Systems; IM\&DS=Industrial Management and Data Systems; I\&M=Information and Management; ISR=Information Systems Research; IJIM=International Journal of Information Management; JIT=Journal of Information Technology; JMIS= Journal of Management Information Systems; MISQ= Management Information Systems Quarterly; CMR=California Management Review; $\mathrm{DS}=$ Decision Sciences; HBR=Harvard Business Review; LRP= Long Range Planning; MS=Management Science; SMR/MITSMR=Sloan Management Review/MIT Sloan Management Review; OMEGA=OMEGA; OS=Organization Science.

Table 2: Number of articles on IS outsourcing in each journal

\begin{tabular}{|lrr|}
\hline \multicolumn{1}{c}{ Journal } & \multicolumn{1}{c|}{ N } & \multicolumn{1}{c|}{} \\
JIT & 21 & 16.0 \\
I\&M & 16 & 12.2 \\
CACM, IJIM & 12 & 9.2 \\
IM\&DS & 11 & 8.4 \\
EJIS & 10 & 7.6 \\
JMIS, & 9 & 6.9 \\
SMR/MITSMR & & \\
ISR, MISQ & 6 & 4.6 \\
MS & 5 & 3.8 \\
HBR, LRP & 3 & 2.3 \\
CMR, DSS, OMEGA & 2 & 1.5 \\
DS, OS & 1 & 0.8 \\
TOTAL & 13 & 100. \\
& 1 & 0 \\
\hline
\end{tabular}


Table 3. Research methodologies in IS outsourcing

\begin{tabular}{|lcccc|}
\hline & $\begin{array}{c}\text { Until 1995 } \\
(\%)\end{array}$ & $\begin{array}{c}1996-2000 \\
(\%)\end{array}$ & $\begin{array}{c}\text { Since } 2001 \\
(\%)\end{array}$ & Total (\%) \\
Total & $17 ; 13.0$ & $12 ; 9.2$ & $19 ; 14.5$ & $48 ; 36.6$ \\
Theoretical & & & & \\
Conceptual & $4 ; 3.1$ & $1 ; 0.8$ & $2 ; 1.5$ & $7 ; 5.3$ \\
Illustrative & $8 ; 6.1$ & $3 ; 2.3$ & $9 ; 6.9$ & $20 ; 15.3$ \\
Applied-Concept & $5 ; 3.8$ & $8 ; 6.1$ & $8 ; 6.1$ & $21 ; 16.0$ \\
Total Empirical & $18 ; 13.7$ & $28 ; 21.4$ & $37 ; 28.2$ & $83 ; 63.4$ \\
Case studies & $9 ; 6.9$ & $11 ; 8.4$ & $13 ; 9.9$ & $33 ; 25.2$ \\
Field studies & $8 ; 6.1$ & $11 ; 8.4$ & $18 ; 13.7$ & $37 ; 28.2$ \\
Case \& Field & $0 ; 0.0$ & $3 ; 2.3$ & $4 ; 3.1$ & $7 ; 5.3$ \\
studies & $1 ; 0.8$ & $3 ; 2.3$ & $2 ; 1.5$ & $6 ; 4.6$ \\
Other empirical & & & & \\
studies & & & & \\
TOTAL & $35 ; 26.7$ & $40 ; 30.5$ & $56 ; 42.7$ & $131 ;$ \\
& & & & 100.0 \\
\hline
\end{tabular}

\section{Table 4: Topics in IS outsourcing}

\begin{tabular}{|lrrrr|}
\hline & Until & $1996-$ & Since & Total(\%) \\
& $1995(\%)$ & $2000(\%)$ & $2001(\%)$ & \\
Outsourcing from the perspective of the & $44 ; 21.4$ & $31 ; 15.1$ & $25 ; 12.1$ & $100 ;$ \\
client & & & & 48.7 \\
Success factors & $0 ; 0.0$ & $4 ; 1.9$ & $4 ; 1.9$ & $8 ; 3.9$ \\
Reasons & $15 ; 7.3$ & $9 ; 4.3$ & $4 ; 1.9$ & $28 ; 13.6$ \\
Risks & $8 ; 3.9$ & $4 ; 1.9$ & $9 ; 4.3$ & $21 ; 10.2$ \\
Decision-making & $8 ; 3.9$ & $6 ; 2.9$ & $5 ; 2.4$ & $19 ; 9.2$ \\
General view & $13 ; 6.3$ & $8 ; 3.9$ & $3 ; 1.4$ & $24 ; 11.7$ \\
Outsourcing from the perspective of the & $4 ; 1.9$ & $8 ; 3.9$ & $21 ; 10.2$ & $33 ; 16.0$ \\
provider & & & & \\
ASP & $0 ; 0.0$ & $0 ; 0.0$ & $12 ; 5.8$ & $12 ; 5.8$ \\
Global Outsourcing & $3 ; 1.4$ & $3 ; 1.4$ & $7 ; 3.4$ & $13 ; 6.3$ \\
Providers & $1 ; 0.4$ & $5 ; 2.4$ & $2 ; 0.9$ & $8 ; 3.9$ \\
Outsourcing from the perspective of the & $8 ; 3.9$ & $12 ; 5.8$ & $15 ; 7.3$ & $35 ; 17.0$ \\
relationship & & & & \\
Contract & $4 ; 1.9$ & $6 ; 2.9$ & $4 ; 1.9$ & $14 ; 6.8$ \\
Assessment, price & $1 ; 0.4$ & $2 ; 0.9$ & $2 ; 0.9$ & $4 ; 1.9$ \\
Client-provider relationship & $3 ; 1.4$ & $4 ; 1.9$ & $9 ; 4.3$ & $16 ; 7.8$ \\
Outsourcing from the perspective of & $5 ; 2.4$ & $4 ; 1.9$ & $10 ; 4.8$ & $19 ; 9.2$ \\
Economic Theories & & & & \\
Agency Theory & $1 ; 0.4$ & $0 ; 0.0$ & $2 ; 0.9$ & $3 ; 1.4$ \\
Transaction Cost Theory & $3 ; 1.4$ & $3 ; 1.4$ & $6 ; 2.9$ & $12 ; 5.8$ \\
Other theories & $1 ; 0.4$ & $1 ; 0.4$ & $2 ; 0.9$ & $4 ; 1.9$ \\
Others & $1 ; 0.4$ & $6 ; 2.9$ & $11 ; 5.3$ & $18 ; 8.7$ \\
Nationality & $0 ; 0.0$ & $1 ; 0.4$ & $3 ; 1.4$ & $4 ; 1.9$ \\
IS staff & $1 ; 0.4$ & $2 ; 0.9$ & $5 ; 2.4$ & $8 ; 3.9$ \\
Industry & $0 ; 0.0$ & $3 ; 1.4$ & $3 ; 1.4$ & $6 ; 2.9$ \\
TOTAL & $62 ; 30.2$ & $61 ; 29.7$ & $82 ; 40.0$ & $205 ;$ \\
& & & & 100.0 \\
\hline
\end{tabular}

Table 5: Scope of the IS activities outsourced

\begin{tabular}{|c|c|c|c|c|}
\hline & $\begin{array}{c}\text { Until } 1995 \\
(\%)\end{array}$ & $\begin{array}{c}1996-2000 \\
(\%)\end{array}$ & $\begin{array}{c}\text { Since } 2001 \\
(\%)\end{array}$ & Total (\%) \\
\hline General & $29 ; 22.1$ & $36 ; 27.5$ & $36 ; 27.5$ & $101 ; 77.1$ \\
\hline $\begin{array}{l}\text { Soft. } \\
\text { Development }\end{array}$ & $6 ; 4.6$ & $4 ; 3.1$ & $8 ; 6.1$ & $18 ; 13.7$ \\
\hline
\end{tabular}




\begin{tabular}{|lrrrr|} 
Applications & $0 ; 0.0$ & $0 ; 0.0$ & $11 ; 8.4$ & $11 ; 8.4$ \\
E-Commerce & $0 ; 0.0$ & $0 ; 0.0$ & $1 ; 0.8$ & $1 ; 0.8$ \\
TOTAL & 35;26.7 & $40 ; 30.5$ & $56 ; 42.7$ & $131 ;$ \\
& & & & 100.0 \\
\hline
\end{tabular}


Table 6: Authors publishing the most articles on IS outsourcing

\begin{tabular}{|lllll|}
\hline Author & N & Country & Author & N Country \\
Willcocks, L. & 1 & United Kingdom & Lee, J-N. & 4 China \\
& 1 & & & \\
Lacity, M.C. & 8 & USA & Apte, U.M. & 3 USA \\
Ang, S. & 6 & Singapore & Aubert, B.A. & 3 Canada \\
Cheon, M.J. & 5 & USA, Korea & Chaudhury, A. & 3 USA \\
Feeny, D. & 5 & United Kingdom & Currie, W.L. & 3 United \\
& & & Kingdom \\
Grover, V. & 5 & USA & Kishore, R. & 3 USA \\
Kern, T. & 5 & The Netherlands & Nam, K. & 3 Korea, \\
& & & Australia \\
Rao, H.R. & 5 & USA & Patry, M. & 3 Canada \\
Rivard, S. & 5 & Canada & Smith, M.A. & 3 USA \\
Teng, J.T.C. & 5 & USA & Smith, M.A. & 3 USA \\
Fitzgerald, & 4 & United Kingdom & Straub, D.W. & 3 USA \\
G. & & & \\
Hirschheim, & 4 & USA & Venkatraman, & 3 USA \\
R. & & & N. & \\
\hline
\end{tabular}

Table 7: Countries contributing the most to IS outsourcing research

\begin{tabular}{|lrll|}
\hline \multicolumn{1}{|c}{ Country } & $\mathrm{N}$ & Country & $\mathrm{N}$ \\
USA & 15 & Finland & 5 \\
& 4 & & \\
United & 54 & Norway & 5 \\
Kingdom & & & \\
Canada & 18 & Hong & 4 \\
& & Kong & \\
Australia & 9 & France & 3 \\
Singapore & 8 & Taiwan & 3 \\
Korea & 7 & India & 2 \\
Spain & 6 & Japan & 2 \\
The & 6 & Ireland & 1 \\
Netherlands & & & \\
China & 5 & & \\
\hline
\end{tabular}

Figure 1: Number of articles on IS outsourcing

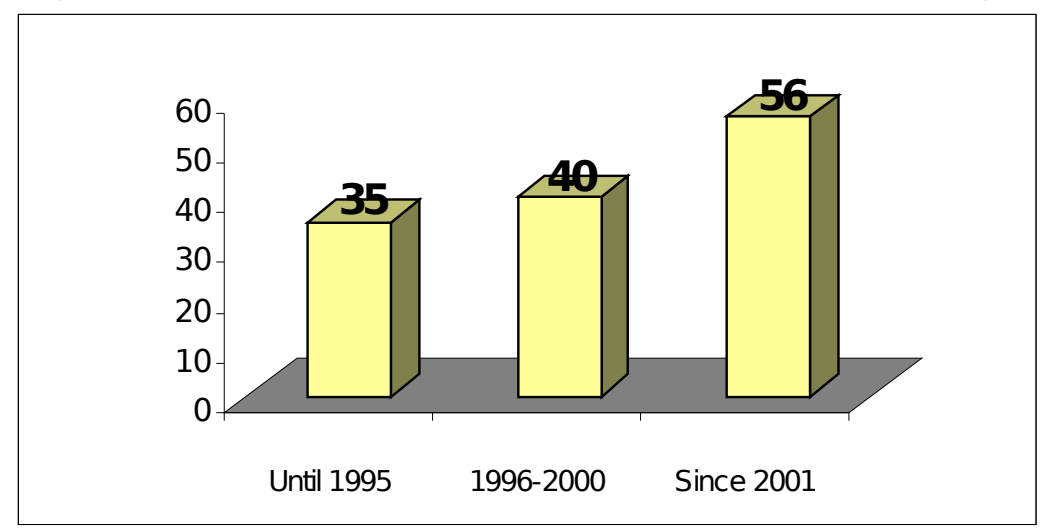


Figure 2: Research methodologies

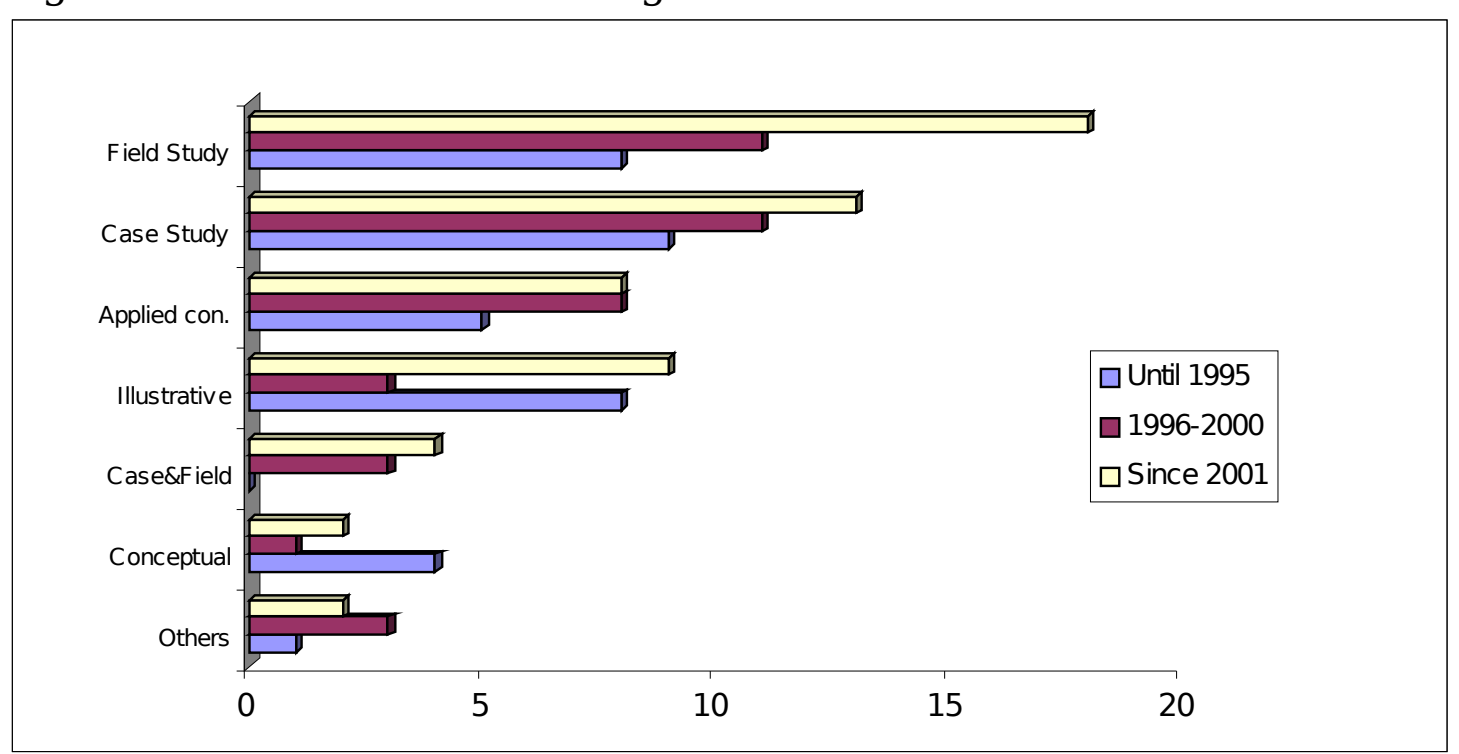

Figure 3: The most frequent topics in IS outsourcing

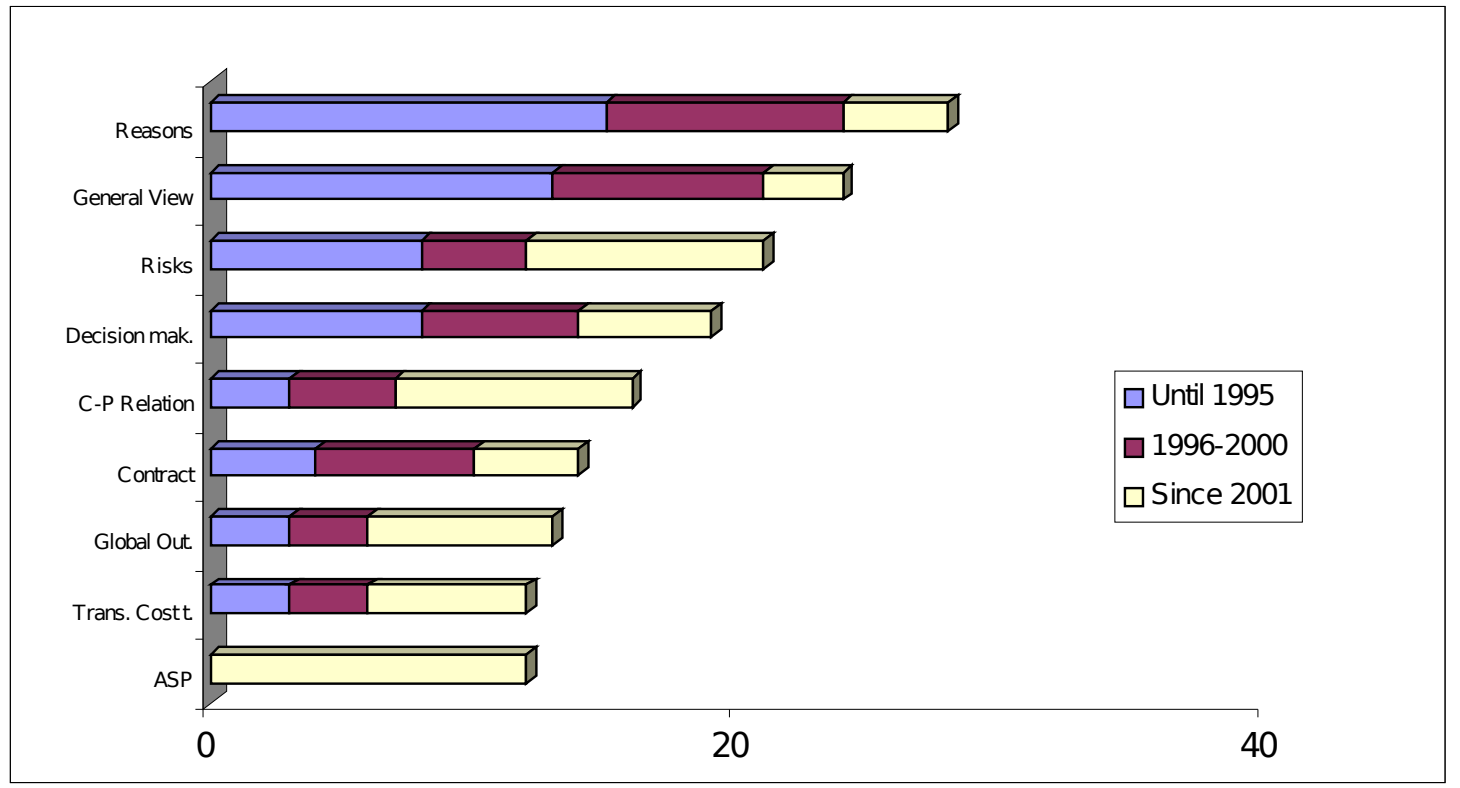

Figure 4: General areas in IS outsourcing 


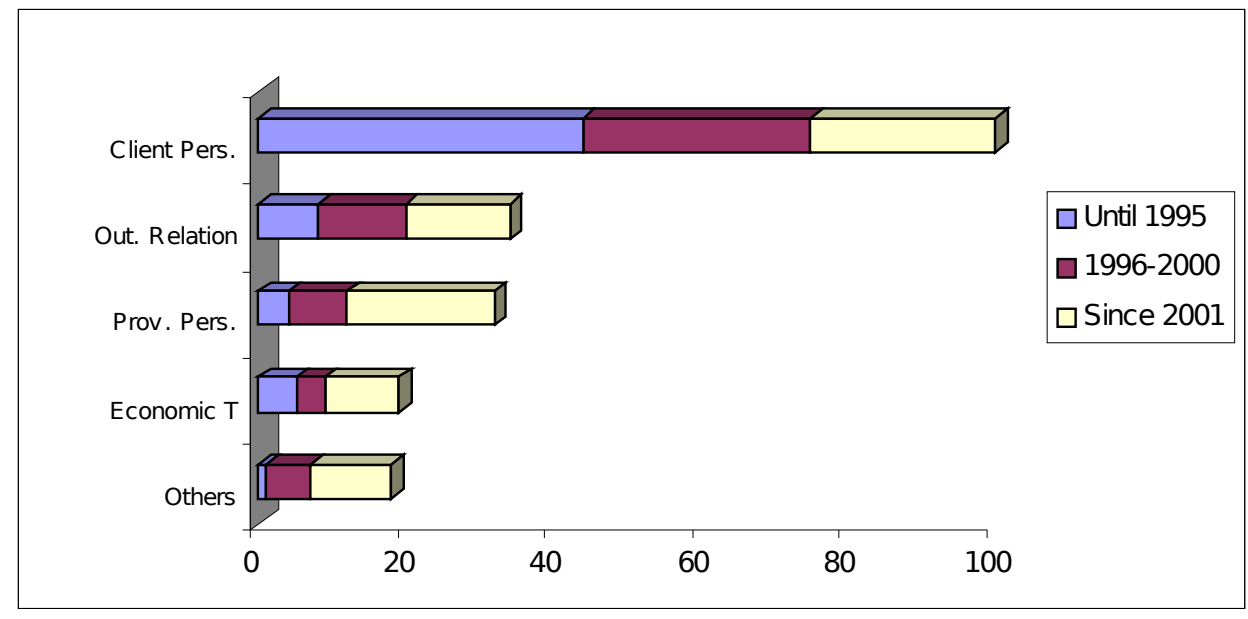

